\title{
Some physical characteristics of dietary fibres and their influence on the microbial ecology of the human colon
}

\author{
By Peter J. Van Soest, Division of Nutritional Sciences and Department of \\ Animal Science, Cornell University, Ithaca, $N \mathrm{I}_{4} 8_{53}, U S A$
}

Current thinking on the subject of dietary fibre tends to emphasize an inclusive definition that overlooks disparate characteristics of individual fibres and their components. The current definition includes all carbohydrate and some noncarbohydrate components that are resistant to mammalian enzymes. The analytical approach proposes to resolve the differences between sources of fibre by characterizing the different proportions of cellulose, hemicellulose, pectin, etc. and in turn resolving these into their respective component sugars.

Forage analysis, largely applied to nutrition of ruminants, has emphasized the nutritional non-uniformity of cellulose and hemicellulose despite similarities in chemical linkage and structure of the respective components among different species of forage plants. This has led to the suggestion that intrinsic differences among celluloses are due to macromolecular interactions rather than to their intrinsic structure and composition (Van Soest, 1982).

This paper applies the same view to dietary fibre in human nutrition and provides some evidence that physical properties are major determinants of the biological properties of dietary fibre in the human digestive tract.

\section{Human feeding study}

Much of the preliminary information which has emphasized the importance of physicochemical properties of dietary fibre was obtained in a human feeding experiment conducted at Cornell in January-March $1977^{\circ}$. The study included twenty-four young men who were given controlled diets for $80 \mathrm{~d}$. Faeces and urine were collected so that total digestion balances could be obtained. Four sources of fibre were given in the form of prepared breads supplementing a low-fibre basal diet that consisted mainly of meat, eggs and mashed potatoes. Bread on the low-fibre diet was a white bread without any added fibre. The diets were nutritionally adequate for the supply of all known nutrient requirements. All food was taken in a metabolic ward although subjects were free to attend classes and jobs. Each carried toilet collection equipment throughout their daily routine.

Dietary intakes were measured and adjusted to maintain body-weight. The test diets included coarse wheat bran and the same bran finely ground, Solka floc (a wood-derived cellulose), cabbage and a low-fibre (white bread) control. Fibre

-Human feeding experiment conducted at Cornell in 1977 was supported in part by a grant from the National Cancer Institute DHEW and approved by the Cornell University Committee on Human Subjects. 
sources were given at equalized levels relative to dietary fibre determined as neutral-detergent fibre plus pectin. The experimental design followed a factorial sequence of diets (given for 2-week periods to twelve subjects). A second group of twelve subjects were fed on the same diet for 8 weeks to ascertain longer-term effects. Details of various results of the study have been published elsewhere (Heller et al. I980; Ehle et al. I98I; Van Soest, 198I; Van Soest et al. I983a; Wrick et al. 1983).

The study was designed to compare the effects of grinding and particie size (coarse $v$. fine bran), while cabbage $v$. bran compared vegetable (highly fermentable and hydratable) with less-fermentable and hydratable brans. The wood cellulose represents a finely-divided crystalline, slow-fermenting substrate of the lowest hydration and cation exchange capacity (Van Soest \& Robertson, 1976).

Rate of passage (transit) was measured by administering solid and liquid markers simultaneously once weekly. Markers included plastic cubes $\left(2 \mathrm{~mm}^{3}\right.$, twenty-five per dose), chromium-stained (mordanted) bran, polyethylene glycol (PEG) and brilliant blue dye. Only values for $\mathrm{Cr}$ and PEG are presented in the present paper (Table I). A comparison of different markers is published elsewhere (Van Soest et al. $1983 a$ ).

The ability of the fibre sources to increase rate of passage and reduce retention time in the digestive tract varied widely (Table 1 ). Coarse bran elicited the shortest retention times while those for cabbage did not differ from those for the low-fibre control. Fine grinding of bran significantly decreased the passage effect consistent with the assumption that volume is related to the rate of passage. Fine grinding of bran markedly reduces its volume through collapse of the cellular structure, a

Table I. Fibre characteristics, passage criteria and stool characteristics

\begin{tabular}{|c|c|c|c|c|c|}
\hline Component ... & $\begin{array}{c}\text { Coarse } \\
\text { bran }\end{array}$ & $\begin{array}{l}\text { Fine } \\
\text { bran }\end{array}$ & $\begin{array}{c}\text { Solka } \\
\text { floc }\end{array}$ & Cabbage & $\begin{array}{c}\text { Low-fibre } \\
\text { control }\end{array}$ \\
\hline \multicolumn{6}{|l|}{ Fibre characteristics } \\
\hline Intake ( $\mathrm{g} / \mathrm{d})$ & 21 & 21 & 23 & 24 & 4 \\
\hline Digestibility & 0.52 & 0.54 & 0.25 & 0.75 & 0.74 \\
\hline Particle size mean (mm) & 0.74 & 0.17 & 0.14 & 0.48 & - \\
\hline \multicolumn{6}{|l|}{ Particulate marker (chromium mordant) } \\
\hline Mean retention time $(\mathrm{h})$ & $5^{2^{a}}$ & $68^{\mathrm{c}}$ & $60^{\mathrm{b}}$ & $74^{\mathrm{c}}$ & $74^{\mathrm{c}}$ \\
\hline Large bowel retention time $(\mathrm{h})$ & 18 & 22 & 22 & 28 & 25 \\
\hline \multicolumn{6}{|l|}{ Liquid marker (PEG) } \\
\hline Mean retention time $(\mathrm{h})$ & $39^{\mathrm{a}}$ & $64^{c}$ & $57^{b}$ & $7^{1^{c}}$ & $69^{c}$ \\
\hline Large bowel retention time (h) & $18^{\mathrm{a}}$ & $27^{\mathrm{b}}$ & $25^{\mathrm{b}}$ & $25^{\mathrm{b}}$ & $3 \mathrm{I}^{\mathrm{b}}$ \\
\hline \multicolumn{6}{|l|}{ Stool characteristics } \\
\hline 'Total water $(\mathrm{g} / \mathrm{d})$ & $\mathrm{I} 2 \mathrm{I}^{\mathrm{a}}$ & $95^{c}$ & $110^{b}$ & $86^{d}$ & $78^{\mathrm{d}}$ \\
\hline Water $(\mathrm{g} / \mathrm{kg})$ & $77^{\mathrm{a}}$ & $73^{c}$ & $74^{\mathrm{b}}$ & $76^{2}$ & $74^{\mathrm{b}}$ \\
\hline Water:faecal fibre & $6 \cdot 5^{c}$ & $10 \cdot 0^{b}$ & $12 \cdot 2^{b}$ & $22 \cdot 2^{2}$ & - \\
\hline Metabolic nitrogen (g digestible fibre) & $0.12^{\mathrm{d}}$ & $0.06^{c}$ & $0.09^{b}$ & $0.03^{2}$ & - \\
\hline
\end{tabular}


characteristic shared by the finely-ground Solka floc. The rates of liquid and particulate passage were very similar, a surprise since in many animal species liquid has a shorter retention time than particles (Uden \& Van Soest, 1982). The capacity of fibre to affect passage seems to depend on the amount and volume of the indigestible residue: cabbage had no significant effect, while finely-ground Solka floc (less-well digested) was more effective than fine wheat bran. Grinding also affected faecal composition and stool volume, reducing the faecal volume primarily as a result of reduced faecal water (Table I). Faeces from fine-bran diets contained less water than those from the control diet, while Solka floc produced no change in water content. Only cabbage and bran increased faecal water content. These diets also produced the largest increase in faecal nitrogen which is a likely measure of faecal microbial output (Van Soest, 1981). All fibre diets increased the number of defaecations.

The digestion of the fibre sources was highest for cabbage and lowest for Solka floc. Prolonged feeding of Solka floc did not induce cellulolytic fermentation but appeared to have a depressing effect on the sequential diet. One subject given Solka floc was able initially to ferment more than $60 \%$ of the cellulose in this source but totally lost this ability on prolonged feeding. This was verified by examination for cellulolytic bacteria in the faeces. The digestion of hemicellulose in Solka floc also tended to decline with time in three subjects given it for extended periods (Fig. I).

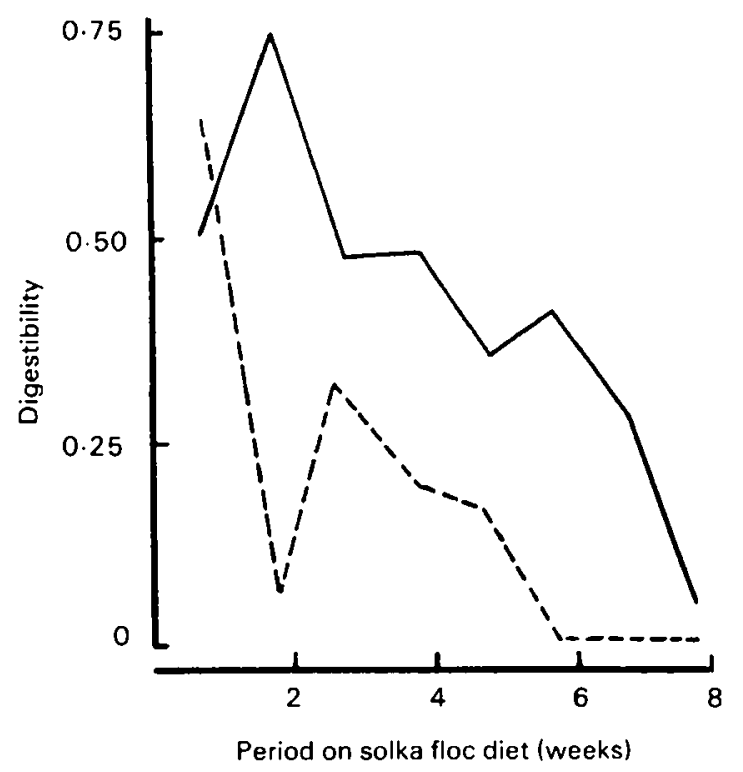

Fig. 1. Digestion of cellulose (- - - ) and hemicellulose (-_ - in subjects receiving Solka floc (wood cellulose) over an extended period in the form of bread at about $21 \mathrm{~g} / \mathrm{d}$. Hemicellulose values are the average for three subjects. Cellulose digestibilities are from a single individual, the only one of the three who had crystalline cellulose-digesting bacteria in his gut initially. However, he lost these bacteria at about day 40 . Subsequent faecal culture from this subject indicated that he did not regain crystalline cellulolytic bacteria over a 2-year period. 
The wood product, a finely-divided crystalline cellulose preparation, reduced cellulose digestion in sequential diets given in periods after the wood cellulose (Van Soest, I98I). Ruminant fermentation theory would have predicted induction of a utilizing-microbial population when offered a potentially-degradable substrate (Fig. I). In fact the very opposite occurred and even affected hemicellulose digestion in the long-term.

The fermentation of Solka floc by rumen organisms exhibited about $17^{-20} \mathrm{~h}$ of lag which is much longer than for natural fibre sources. Also the mean calculated retention time in the colon was about $20 \mathrm{~h}$ (range $5-40 \mathrm{~h}$ ) for the human subjects (Van Soest, 1981). Since microbial survival in continuous fermentation systems is dependent on generation time being shorter than turnover time, possible loss of cellulolytic bacteria might be related to their attachment to substrate (Latham, I980) and their growth limited by the lag time and sequential rate of digestion. Ingestion of fibre increased the rate of passage and was likely to have decreased colonic retention below the limit required for regeneration and survival.

Fine grinding of fibre is also known to produce negative effects in rumen digestion (Berger et al. 1980). Small particles have faster transit in ruminants, whereas transit of small particles is slower in non-ruminants. This difference is probably due to the retentive character of the reticulo-rumen-omasal system and the need for rumination to process coarser material. Non-ruminants have no apparent mechanism for retention of coarse fibre, and our human results indicate about equal passage rates for liquid and particulate matter. A question remains: does grinding have a negative effect per se on cellulolytic bacteria? Grinding reduces intracellular space where fibre-digesting bacteria tend to reside (Akin, 1980). Elimination of this space could expose bacteria to greater competition and predation. Collapse of structure also decreases water-holding capacity and is associated with lower faecal water content.

The respective fibres induced varied loss in faecal N (Table I). The loss was largest for coarse bran and cabbage and the least for wood cellulose. Most of this $\mathrm{N}$ is in microbial cells and is therefore an index of microbial efficiency (Mason, 1979). When expressed as N/g fibre digested, coarse bran elicited the greatest efficiency and cabbage the least (Van Soest, 1981). The difference in the carbon balance would be in volatile fatty acids. The ranking of the microbial efficiencies is in order of the passage rates where shorter retention and more rapid turnover reduce microbial maintenance and increase net cells per $g$ substrate fermented ( $V$ an Nevel \& Demeyer, 1979).

The microbial excretion could be important as a detoxification mechanism (Visek, 1978) since increased microbial cell synthesis would more effectively scavenge degradable nitrogenous substances and bind them into microbial cells which are eventually voided.

A further effect is in relation to mineral balance. Preliminary data (P. J. Van Soest and L. H. P. Jones, unpublished results) indicate that calcium, zinc and iron balances were most favourable on the cabbage diet compared with the low-fibre control diet. Mineral losses of $\mathrm{Fe}$ and $\mathrm{Zn}$ were correlated with faecal loss of 
microbial matter. One mechanism of mineral loss may be in the binding of essential elements in microbial cells.

The direct binding of metals by dietary fibre did not seem to be a significant factor in this study. Phenolic groups on lignin and tannins can bind $\mathrm{Cu}$ and $\mathrm{Zn}$ in the unavailable form (Klevay $\&$ Van Soest, $198 \mathrm{I}$ ). However, this is a property of red wheats and not of white-wheat bran which was used in the present study.

\section{Physical properties}

The results of the Cornell study help sort out the association between physicochemical properties and dietary effects of dietary fibre. Important physical properties are hydration capacity and cation exchange. The hydration capacity tends to set the volume occupied by the fibre in the hydrated state in the gastrointestinal tract (Stephen \& Cummings, 1979) while the cation exchange involves binding of metal ions, water and other substances.

Water-holding capacity. This property is one for which methodological development has been limited. We have employed two methods, filtration and osmotic suction. Filtration, like the centrifugation method of McConnell et al. (1974), is only applicable to insoluble dietary fibre sources; gums, gels or partially-soluble matter are unmeasurable by this procedure. The osmotic procedure (Robertson \& Eastwood, 198I), using membrane and polyethylene glycol solutions, is applicable to non-dialyzable soluble substances.

Results obtained for the dietary fibre sources given in the Cornell human study are shown in Table 2. Measured hydration capacities are lower than the apparent faecal hydration but seem to relate the fibre sources in relative order. Reasons for

Table 2. Composition $(\mathrm{g} / \mathrm{kg})$ and physical properties of sources of dietary fibre

\begin{tabular}{|c|c|c|c|c|c|c|c|c|}
\hline Source of fibre & $\begin{array}{l}\text { Insoluble } \\
\text { NDF }\end{array}$ & $\begin{array}{l}\text { Soluble } \\
\text { fibre }\end{array}$ & $\mathrm{HC}$ & Cellulose & Lignin & $\begin{array}{l}\text { WHC } \\
(\mathrm{ml} / \mathrm{g})(\mathrm{m}\end{array}$ & $\begin{array}{l}\mathrm{CEC} \\
\mathrm{nol} / \mathrm{kg})^{\bullet}\end{array}$ & $\begin{array}{c}\text { Ferment- } \\
\text { ability } \\
\text { (/g isolated } \\
\text { fibre) }\end{array}$ \\
\hline Coarse bran & $44 \mathrm{I}$ & 20 & 309 & 93 & 39 & $\mathrm{I} \cdot 3$ & 870 & 0.71 \\
\hline Fine bran $\ddagger$ & 393 & 30 & 272 & 89 & $3 I$ & $I \cdot I$ & 870 & 0.72 \\
\hline Wood cellulose & 1000 & 。 & 26 & 945 & 28 & $1 \cdot 0$ & 50 & 0.94 \\
\hline $\begin{array}{l}\text { Cabbage (ethanol- } \\
\text { insoluble powder) }\end{array}$ & 443 & 287 & 73 & 3 I I & IO & $3 \cdot 0$ & 920 & $0.9 \mathrm{I}$ \\
\hline Citrus pectin & 0 & 1000 & 0 & 0 & 0 & $5 \cdot 0$ & 2270 & 0.98 \\
\hline Psyllum gum & 44 & 889 & - & 41 & 3 & $3 \cdot 2$ & 30 & $0.5^{6}$ \\
\hline $\begin{array}{l}\text { Maillard product } \\
\text { Lucerne (Medicago }\end{array}$ & 742 & - & - & - & 727 & I. 7 & 370 & 0 \\
\hline sativa) & $53^{\circ}$ & 40 & IIo & 339 & 75 & $1 \cdot 8$ & 360 & 0.57 \\
\hline
\end{tabular}

$\mathrm{NDF}$, neutral-detergent fibre; HC, hemicellulose; WHC, water-holding capacity; CEC, cation exchange capacity.

-mmol hydrogen ion equivalent, as measured by the displacement by copper.

+ Fermentability at $48 \mathrm{~h}$ with rumen fluid (NDF in the case of insoluble sources and alcoholinsoluble matter in the case of soluble sources).

$\ddagger$ Grinding of bran systematically reduces fibre values. Part is the loss of very fine matter, but not all is recoverable. Discrepancy on summing components relative to total fibre involves some protein and ash. 
the greater amount of water associated with faecal fibre are (a) the microbial fraction contributes to the capacity and is not considered, and (b) the possibility that 8 atmospheres osmolar pressure used in the measurement are too high leading to low values (Horvath, 1983).

Cation exchange. Cation adsorption appears to be important in the formation of cationic bridges as a mechanism for bile acid, fatty acid and mineral adsorption in the upper intestine (Kay, I982). The affinity of $\mathrm{Cu}$ for carboxylic acid groups has been employed in pectin precipitation (Keijbets \& Pilnik, 1972; Kausar \& Nomura, I 980 ) and in the determinations of cation exchange capacity (CEC) of dietary fibre (McBurney et al. 1981).

Values of CEC are shown in Table 2 for various dietary fibres. Pectin, lucerne (Medicago sativa) and a Maillard-product preparation have been included in addition to the dietary sources used in the human study (Van Soest et al. $1983 b$ ). Citrus pectin has been used in many studies related to bile acid metabolism; the lucerne was one diet in a pig-feeding study and was compared with bran and Solka floc (Ehle et al. 1982). The Maillard product was prepared from equivalent quantities of sucrose and glycine according to the procedure of Olsson et al. (1978).

Table 2 contains estimates of CEC, with pectin having the greatest amount of $\mathrm{Cu}$ adsorption per unit weight. Cabbage, with one-third of its dietary fibre value derived from pectin, similarly has a substantial CEC value $(920 \mathrm{mmol} \mathrm{H}+/ \mathrm{kg})$. The coarse bran and lucerne were neutral-detergent-fibre preparations. In these preparations lignin, with both carboxyl and hydroxyl groups on the phenylpropanoid units, probably has an important role in CEC. CEC may also be contributed to by the hemicellulose fraction which contains glucuronic and galacturonic acid components. Lignin and hemicellulose appeared to be the primary source of $\mathrm{Cu}$ adsorption in wheat bran. Lucerne and the Maillard product have more moderate CEC values of 360 and $370 \mathrm{mmol} \mathrm{H}^{+} / \mathrm{kg}$ respectively. Binding by the glycine-sucrose Maillard product was primarily a lignin-like effect. Wood cellulose had very little cation exchange.

CEC appears to be associated with hydratability and ease of fermentation (Table 2). Van Soest \& Robertson (1976) found a correlation of +0.7 between CEC and hydration capacity. Many crystalline delignified celluloses exhibit long lags and slow rates of fermentation with rumen organisms (Van Soest, 1973). A comparison of fibre types is shown in Fig. 2. Cabbage, rich in pectin and uncrystalline, unlignified cellulose, ferments rapidly to completion in $10 \mathrm{~h}$, while wheat bran represents an intermediate situation. The Solka floc source of wood cellulose exhibits about $20 \mathrm{~h} \mathrm{lag}$ before fermentation begins. Complete fermentation requires $72-96 \mathrm{~h}$.

Delignification may result in loss of hydration capacity and CEC, factors that may be required for the attachment of cellulolytic organisms to their substrate. The delay in initiation of attachment might be one cause of the lag in fermentation of the Solka floc and other delignified substrates (McBurney et al. 1981).

Of the respective sources, the Maillard product is the most peculiar. Although this material has not been systematically investigated with regard to human 


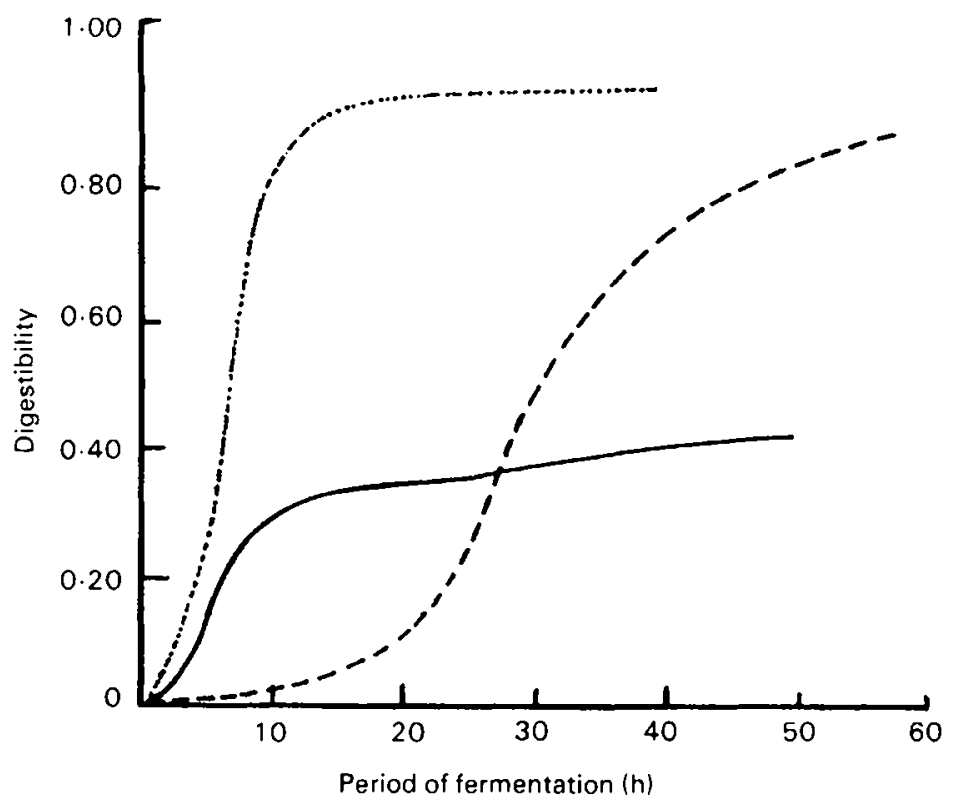

Fig. 2. Cummulative in vitro fermentation of dietary fibre sources (cabbage (......), Solka floc $(----)$, wheat bran $(--)$ ) with time using mixed rumen organisms. Lignification is the principal factor setting an ultimate limit on fermentability. This effect is greatest in bran. Patterns obtained with human faecal inoculum were similar for cabbage and bran, but differed widely in the case of Solka floc depending on the donor (values from J. L. Jeraci, unpublished results). Range in estimated individual human colonic retention was from 5 to $40 \mathrm{~h}$. Subjects with shorter retention times $(<.20 \mathrm{~h}$ ) did not ferment the Solka floc (Van Soest, $198 \mathrm{r}$ ).

feeding, much or most of the crude lignin in human foods could be from this source because of its generation in baking and frying. Preliminary feeding of a synthetic Maillard product to rats (J. L. Jeraci and P. J. Van Soest, unpublished results) produced nitrogenous losses in faeces of about three times the quantity of $\mathrm{N}$ in the Maillard product given. The composition and nature of this faecal loss remain to be investigated. The rats given the Maillard product also exhibited irritability, not shown by those given the control diet or Solka floc.

\section{Integrative model of fibre action}

The definition of dietary fibre to include all substances of plant origin that are resistant to mammalian digestive enzymes, results in the inclusion of traditional insoluble sources as well as soluble gums, including pectin, which have little physical appearance as fibre. The diversity of categories of fibre lead to a need for comprehending the various physical properties and their nutritional and physiological consequences. The interrelationships of fibre type and host responses are shown in Fig. 3.

Solubility, hydration capacity, CEC and fermentability are attributes of all sources, but particle size is peculiar to insoluble fibres and affects their hydration capacity and passage characteristics. Soluble gums are apt to possess greater 


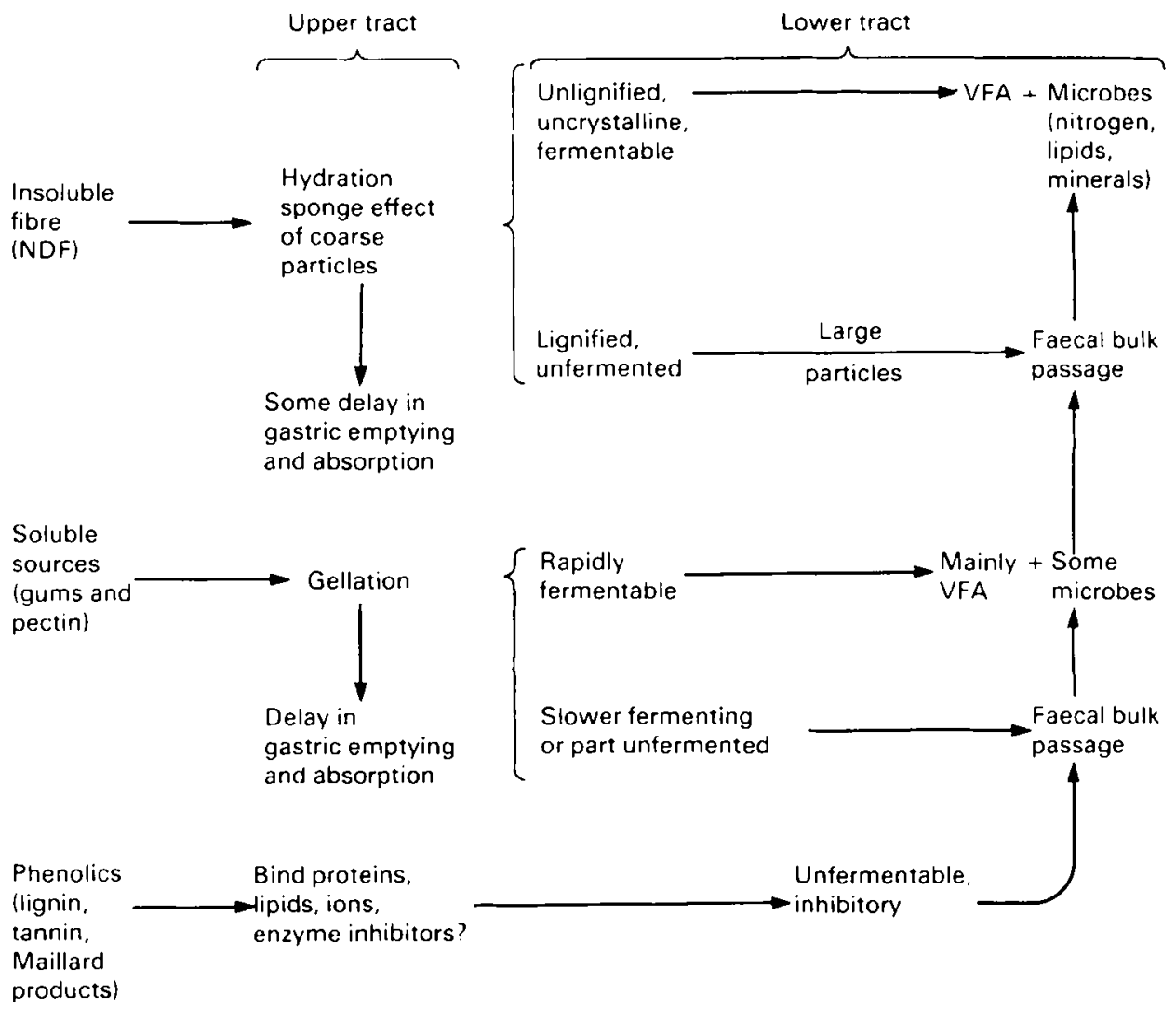

Fig. 3. Diagram showing a model relating type of fibre with gastrointestinal responses in humans. NDF, neutral-detergent fibre; VFA, volatile fatty acids.

hydration capacity than insoluble sources and also be more fermentable, a factor restricting physical effects of gums to the upper digestive tract (Jenkins \& Wolever, 1981). On the other hand some soluble sources, i.e. psyllium, contain an unfermentable soluble residue which retains some gellation characteristics. Fibre sources that have a residual unfermented volume will accelerate passage and affect microbial efficiency and yield and through that mechanism promote loss of faecal $\mathrm{N}$, fat (Ehle et al. $198 \mathrm{I}$ ) and perhaps minerals. Volatile fatty acids are by-products of microbial metabolism and can have their own metabolic effect by substituting for digestible carbohydrate.

From this view point, quality of dietary fibre can be ranked by parallel criteria. Coarse insoluble fibre is more effective than finely ground and processed fibres. Gums are probably more effective than other fibres in effecting upper tract responses such as delaying absorption or gastric emptying (Jenkins \& Wolever, 1981). Fibres of moderate fermentability are preferable to those of very rapid or very slow fermentability. The interaction of undigested fibre that promotes passage with fermentable fibre is important in promoting faecal microbial losses. 


\section{REFERENCES}

Akin, D. E. (1 980). Applied Environmental Microbiology 39, 242-252.

Berger, L. L., Klopfenstein, J. T. \& Britton, R. A. (1980). Fournal of Animal Science 50, 745-749.

Ehle, F. R., Jeraci, J. L., Robertson, J. B. \& Van Soest, P. J. (1982). Fournal of Animal Science 55, $1071-1081$.

Ehle, F. R., Robertson, J. B. \& Van Soest, P. J. ( I98 r). Fournal of Nutrition I12, 1 58-166.

Heller, S. N., Hackler, L. R., Rivers, J. M., Van Soest, P. J., Roe, D. A., Lewis, B. A. \& Robertson, J. B. (1 980). American Journal of Clinical Nutrition 33, $1734-1744$.

Horvath, P. J. ( 1983 ). The contents and some physico-chemical properties of dietary fiber. Doctorial Dissertation, Cornell University, Ithaca, NY.

Jenkins, D. J. A. \& Wolever, T. M. S. (I98I). Proceedings of the Nutrition Society 40, $227-235$.

Kausar, P. \& Nomura, D. (1980). Fournal of the Faculty of Agriculture, Kyushu University, Japan 25, 6I-7I.

Kay, R. M. (1982). Fournal of Lipid Research 23, $221-242$.

Keijbets, M. J. H. \& Pilnik, W. (1972). Potato Research I7, 169-1 77.

Klevay, L. M. \& Van Soest, P. J. (1981). Federation Proceedings 40, 854.

Latham, M. J. (1980). Microbial Adhesions to Surfaces, vol. 19, pp. 339-350 [R. C. W. Berkeley, editor]. London: Society of Chemistry and Industry.

McBurney, M. I., Van Soest, P. J. \& Chase, L. E. (198I). Proceedings of the Cornell Nutrition Conference, pp. 16-23.

McConnell, A. A., Eastwood, M. A. \& Mitchell, W. D. (1974). Fournal of the Science of Food and Agriculture 25, $1457^{-1} 4^{6}$.

Mason, V. C. (1979). Zeitschrift für Tierphysiologie, Tierernährung und Futtermittelkunde 41, $121-131$.

Olsson, K., Pernemalm, P. \& Theander, O. (1978). Acta Chimica Scandinavica B32, $249-256$.

Robertson, J. A. \& Eastwood, M. A. (198I). British Yournal of Nutrition 46, 247-255.

Stephen, A. M. \& Cummings, J. H. (1979). Gut 20, 722-729.

Uden, P., Colucci, P. E. \& Van Soest, P. J. (1980). Fournal of the Science of Food and Agriculture $31,625-632$.

Uden, P. \& Van Soest, P. J. (I982). Animal Science and Food Technology 7, 35-44.

Van Nevel, C. J. \& Demeyer, D. I. (1979). European Journal of Applied Microbiology and Biotechnology 7, $111-120$.

Van Soest, P. J. (1973). Federation Proceedings 32, 1804-1808.

Van Soest, P. J. ( (981). In Banbury Report 7: Gastrointestinal Cancer: Endogenous Factors, pp. 6I-69 [W. R. Bruce, P. Correa, M. Lipkin, S. R. Tannenbaum and T. D. Wilkins, editors]. Cold Spring Harbor, NY: Cold Spring Harbor Laboratory.

Van Soest, P. J. (1982). Nutritional Ecology of the Ruminant. Corvallis, OR: O \& B Books.

Van Soest, P. J., Horvath, P. J., McBurney, M. I. \& Allen, M. S. ( $983 a$ ). Unconventional Sources of Dietary Fiber, Symposium series 2I4, Pp. I35-14I [I. Furda, editor]. Washington DC: American Chemical Society.

Van Soest, P. J. \& Robertson, J. B. (1976). Dietary Fiber. Proceedings of the Miles Symposium, Nutrition Society of Canada, pp. 13-25 [W. W. Hawkins, editor]. Ontario: Miles Laboratories.

Van Soest, P. J., Uden, P. \& Wrick, K. F. (1 $983 b)$. Nutrition Reports International 27, 17-28.

Visek, W. J. (1978). American Journal of Clinical Nutrition 31, Suppl. 216-220.

Wrick, K. L., Robertson, J. B., Van Soest, P. J., Lewis, B. A., Rivers, J. M., Roe, D. A. \& Hackler, L. R. (1983). Fournal of Nutrition I $13, \mathrm{I}_{4} 64-1479$. 